Scientia Agricola

http://dx.doi.org/10.1590/0103-9016-2015-0195

\title{
Biogas production: litter from broilers receiving direct-fed microbials and an enzyme
}

\section{blend}

Maria Fernanda Ferreira Menegucci Praes ${ }^{1 *}$, Jorge de Lucas Junior ${ }^{1}$, Ana Carolina Amorim Orrico ${ }^{2}$, Marco Antonio Previdelli Orrico Junior², Rafael Gustavo Hermes ${ }^{3}$, José Otávio Berti Sorbara ${ }^{3}$, Karina Ferreira Duarte ${ }^{4}$, Alice Watte Schwingel², Sarah Sgavioli ${ }^{4}$, Carla Heloisa de Faria Domingues ${ }^{5}$, Natália da Silva Sunada ${ }^{1}$

\author{
${ }^{1}$ São Paulo State University/FMVZ - Dept. of Nutrition and \\ Animal Production, Av. Duque de Caxias, 225 - 13635-900 \\ - Pirassununga, SP - Brazil. \\ ${ }^{2}$ Federal University of Grande Dourados/School of \\ Agricultural Science, Rod. Dourados / Itahum, km 12 - \\ Unidade II, C.P. 364 - 79804-970 - Dourados, MS - Brazil. \\ ${ }^{3}$ DSM Nutritional Products - Av. Eng. Billings, 1729 - Prédio \\ 31 - 05321-010 - São Paulo, SP - Brazil. \\ ${ }^{4}$ São Paulo State University/FCAV - Dept. of Animal \\ Morphology and Physiology, Via de Acesso Prof. Paulo \\ Donato Castellane, s/n - 14884-900 - Jaboticabal, SP - \\ Brazil. \\ ${ }^{5}$ Federal University of Grande Dourados/School of Business \\ Administration, Acconting and Economics Science. \\ *Corresponding author <menegucci2002@yahoo.com.br>
}

Edited by: Airton Kunz

Received May 13, 2015

Accepted September 29, 2015
ABSTRACT: The effect of additives used in the feed of broilers on anaerobic bio-digestion of poultry litter was evaluated. Four diets were used: NC: negative control; DFM: NC + 500 ppm direct-fed microbials (DFM) containing Bacillus subtilis and Bacillus licheniformis; ENZ: diet formulated with an enzyme blend (20 ppm phytase, 200 ppm protease and 200 ppm xylanase); DFM+E: ENZ + DFM. Substrates for the anaerobic bio-digestion were prepared with litter from each treatment, containing $4 \%$ total solids (TS). These were used in 16 continuous bio-digesters with a $2 \mathrm{~kg} \mathrm{~d}^{-1}$ load, to determine the production and potential biogas production and composition during an 85-day period. Influent and effluent samples were collected for the amounts of TS and volatile solids (VS), fiber fraction (neutral detergent fiber [NDF], acid detergent fiber [ADF] and lignin), nutrients (N, P and K), and total and thermotolerant coliforms to be determined. For all treatments a reduction in the following effluents was observed as follows: TS $(49,48,48$ and $50 \%)$ VS (70, 54, 55 and $62 \%) \operatorname{NDF}(91,90,95$ and $96 \%) \operatorname{ADF}(89,88,93$ and $94 \%)$ and lignin $(80,76,89$ and $88 \%)$. The efficiency of the treatment for coliforms in bio-digesters was higher than $90 \%$ in the 85-day period in all treatment groups. There was a reduction in biogas and methane production when DFM (5500 and $4000 \mathrm{~mL})$ and DFM + E (5800 and $4100 \mathrm{~mL}$ ) were used, compared to treatments NC (6300 mL and 4400) and ENZ (6400 and $4500 \mathrm{~mL}$ ). The potential production of reduced TS and VS was higher in ENZ (1:00 and $1.74106 \mathrm{~mL} \mathrm{~kg}^{-1}$ ) when compared to NC (0.88 and 1:02 $\left.106 \mathrm{~mL} \mathrm{~kg}^{-1}\right)$, DFM (0.80 and 1:40106 mL kg-1) and $\mathrm{DFM}+\mathrm{E}\left(0.881: 25\right.$ and $\left.106 \mathrm{~mL} \mathrm{~kg}^{-1}\right)$. The additives did not affect the percentage of methane production, and all treatments showed values higher than $70 \%$. Adding enzymes to the diet of broilers influences the litter characteristics and, as a consequence, increases biogas production. The addition of DFM and DFM + E to broiler diets reduced biogas and methane production. Keywords: additives, bio-digestion, bio-digester, methane, livestock residues

\section{Introduction}

The Brazilian poultry industry is considered a reference in both production and promotion of the use of technology, with an outstanding position in world meat production (FAO, 2011). As feed is the major and most important factor in poultry production, measures taken to improve diets become very important. Advances in biotechnology have led to the marketing of products which improve productivity and feed efficiency in broilers when added to feeds (Huyghebaert et al., 2011).

One of the factors that have contributed to the high productivity evident in the poultry industry has been the use of feed additives. Among additives, utilization of direct-fed microbials and exogenous enzymes has been emphasized as these can help improve animal performance and enable the use of feed ingredients that are difficult to degrade (Huyghebaert et al., 2011).

Besides feeding, droppings and waste material produced are also a matter of concern in large-scale poultry production (Bolan, 2010). With this evolution, nutritionists look for alternatives to be used in the formulation of more efficient feed, with low environmen- tal impact which, at the same time, can provide alternative treatment of the residues generated.

Solid residues at the end of each broiler production cycle include the litter and dead animals, and are considered either a resource or a pollutant. Adequate management of these residues with high nutrient content will result in minimum environmental impact. These residues represent potential pollutants for water bodies and also underground water, increasing mineral nutrients, oxygendemanding organic matter, suspended matters and sometimes even pathogenic organisms (Nahm and Nahm, 2004).

The purpose of using technology in residue management is to use the available nutrients, with minimum loss to the environment during processing. Studies are necessary for determining up to what point these can be used, and under which conditions and dimensions, these are actually feasible.

Anaerobic bio-digestion is an outstanding alternative for treating residues related to its sanitary aspects and potential renewable energy generation, besides offering an economic organic and nutrient recycling process (Demirer and Chen, 2005). However, little is known about the influence of diet on the composition of litter to be used in biogas production. 
Thus, this study aimed to evaluate the influence of enzyme additives and direct-fed microbials used in the diet of broilers on the anaerobic bio-digestion of litter in continuous digesters.

\section{Materials and Methods}

Nine hundred day-old broiler chicks from the same breeder flock were used. In a fully randomized design these were distributed into four treatment groups with 9 replicates, 25 birds in each, and six birds per $\mathrm{m}^{2}$ density. The experimental treatments were: NC: negative control diet; DFM: NC diet +500 ppm direct-fed microbials (DFM), with Bacillus subtilis and Bacillus licheniformis; ENZ: NC diet + 20 ppm phytase, 200 ppm protease and 200 ppm xylanase; DFM + E: ENZ diet + DFM diet.

Wood shavings were used as litter material, $0.7 \mathrm{~kg}$ dry matter (DM) per housed bird, so all treatments had the same amount of litter in all boxes $(20 \mathrm{~kg}$ natural matter).

The chicks were vaccinated against Marek's disease, Gumboro (IBD), and fowl pox in the hatchery. At 5 and 21 days of age they were vaccinated against IBD, and at 7 days of age against Newcastle disease, both by ocular administration.

The environmental temperature and relative humidity of the air were recorded daily with digital thermometers placed at the near floor. Curtains and fans were used to ensure the birds' thermal comfort and a 24 hour light program. Feed and water were provided ad libitum throughout the experimental period that was divided into three phases: initial ( 1 to 21 days of age), growing ( 22 to 35 days of age) and final (36 to 42 days of age).

As DFM was used in certain treatments, shoe covers were used during the daily bird management to prevent litter contamination.

Feeds were formulated based on corn and soybean meal (SBM), supplemented with minerals, vitamins and amino acids, to meet each rearing phase (initial, growing and final) nutritional requirements according to NRC recommendations (1994). No growth promoter was used.

The nutritional matrix of each enzyme was taken into account when formulating the diet as follows: $x y-$ lanase supplied $167610^{2} \mathrm{~J}$ metabolizable energy $\mathrm{kg}^{-1}$ feed; phytase supplied $0.15 \%$ available phosphorus and $0.12 \%$ calcium; protease supplied $4 \%$ crude protein, 4 $\%$ digestible arginine, $1 \%$ digestible lysine, $4 \%$ digestible methionine + cystine, $8 \%$ digestible threonine, and $3 \%$ digestible tryptophan. The product used as DFM contained Bacillus subtilis (minimum $0.735 \times 10^{8} \mathrm{UFC}$ $\mathrm{g}^{-1}$ ) and Bacillus licheniformis (minimum $0.735 \times 10^{8}$ $\left.\mathrm{UFC}^{-1}\right)$.

After 42 days, litter was removed from the boxes, identified and placed in plastic buckets. The litter produced was divided to provide the daily load $(2 \mathrm{~kg})$ to the continuous bio-digesters for an 85-day period. The sub- strate was prepared for each loading with a total solids (TS) amount close to $4 \%$. After preparation, solids were separated from the liquid fraction by using 3-mm sieves. The liquid fraction was added to the bio-digesters with a 30-day hydraulic retention time (HRT).

In a fully randomized design, the substrates prepared with litter from broilers fed the different diets listed above were used in the continuous bio-digesters, with four replicates.

The continuous bio-digesters are formed by two different parts: a vessel with the fermenting material and a gasometer. The vessel is made up of a straight PVC cylinder, 300-mm diameter and 1-m long, the extremities being attached to PVC plates, $1.5-\mathrm{m}$ thick. In one of the plates, an inlet pipe was placed to feed the digester; the other extremity had two outlet pipes, one for the bio fertilizer, and another for the gas (Orrico Junior et al., 2010).

The gasometer was consisted of two cylinders $(250$ and $300 \mathrm{~mm}$ diameter) one inside the other, so much so that the space between the two was filled with water ("water seal") reaching a depth of $500 \mathrm{~m}$. The $300 \mathrm{~mm}$ diameter cylinder was attached to a $2.5 \mathrm{~m}$ thick PVC plate. The $250 \mathrm{~mm}$ cylinder had one of its extremities closed by a cap that received the gas produced, the other was capsized in the water seal to store the gas produced. The gasometers were placed on a bench, at room temperature, protected from sunlight and rain (Orrico Junior et al., 2010).

Influent and effluent samples were collected every week during the anaerobic bio-digestion stage to measure the following: acidity using a $\mathrm{pH}$ meter; the total solids (TS) and volatile solids (VS) according to the method described by APHA (2005); the neutral detergent fiber $(\mathrm{NDF})$, acid detergent fiber (ADF), lignin and nitrogen $(\mathrm{N})$ according to the methods proposed by the AOAC (2005).

The amount of phosphorus $(\mathrm{P})$ followed the method described by Malavolta (1989), and the potassium (K) concentrations were determined using an atomic absorption spectrophotometer.

The samples for total and thermotolerant coliform analyses were collected from the influent at the beginning of the experiment and from the effluent after 30,60 and 85 days of treatment in the continuous biodigesters, using the technique with multiple tubes described by APHA (2005).

The vertical displacement of the gasometers was measured to determine the volume of biogas produced daily. The values were multiplied by the area of the gasometers inner cross-section $\left(0.0507 \mathrm{~m}^{2}\right)$. After each reading, the gasometers were reset to zero using the biogas discharge gauge. The biogas volume was corrected to $1.01310^{5} \mathrm{~Pa}$ and $20^{\circ} \mathrm{C}$ conditions, and the accumulated and daily biogas volumes were recorded $(\mathrm{mL})$.

The biogas potential production was calculated using the daily biogas volume data and the amounts of substrate, TS and VS added to bio-digesters, and the TS and 
VS amounts reduced during the anaerobic bio-digestion process. The values were expressed as $\mathrm{mL}$ biogas $\mathrm{kg}^{-1}$ substrate, TS and VS added and reduced.

Composition of the biogas produced in bio-digesters processing poultry litter was analyzed every week to determine the amounts of methane $\left(\mathrm{CH}_{4}\right)$, carbon dioxide $\left(\mathrm{CO}_{2}\right)$ and other gases using a Finigan GC-2001 gas chromatography, equipped with Porapack $\mathrm{Q}$ and Molecular Sieve columns, and a thermal conductivity detector.

The data were analyzed by the SAS ${ }^{\circledast}$ (SAS Institute, 2002) GLM program, and statistically significant means were compared using the Tukey test at $5 \%$ probability.

\section{Results and Discussion}

The anaerobic bio-digestion process reduced all the effluents' $\mathrm{pH}$ resulting in an average between treatments of 7.4 when poultry litter was used in a continuous bio-digester with a 30 day hydraulic retention time (HRT). In accordance with FAO (1996) when the level of methane production reaches stability, $\mathrm{pH}$ was verified when the digesters of the study reached the production of biogas and methane constant, recording values from 7.2 to 8.2 .
TS amounts were found to be reduced in all effluents from treated litters in the bio-digesters. However, the diet given to the birds had no effect $(p>0.05)$ in reducing TS in the bio-digestion process, where the averages were 49,48, 48 and $50 \%$, for NC, DFM, ENZ and DFM + E. Different feed additives that were used caused less VS reduction $(p<0.05)$ when compared to the control treatment, except when the additive association $(\mathrm{DFM}+\mathrm{E})$ was used. All treatments caused a reduction in VS in excess of $50 \%$, showing the efficiency of anaerobic bio-digestion in the degradation of resistant compounds, such as broiler litter (Table 1).

Digestion efficiency can be related to the high amounts of substrate available in VS fermentation. Thus, digestion efficiency was better and obtained a greater reduction in the quantity of VS present when compared to the influent and effluent. The broilers' litter in the substrate showed a clear reduction $(p<0.05)$ in fiber fraction due to sieving, a larger amount of NDF and ADF being found in the effluents of enzyme treatments $(\mathrm{ENZ}$ and DFM + E) (Table 2). This can be related to the presence of xylanase, an enzyme that degrades fibers, reduces litter particles that were difficult to degrade and facilitates the sieving process. The diet did not influence

Table 1 - Amount of Volatile Solids (VS) in influents and effluents (\% and kg) and \% reduction of VS from litter of broilers fed diets with direct-fed microbials (DFM) and enzymes, treated in continuous bio-digesters.

\begin{tabular}{|c|c|c|c|c|c|}
\hline \multirow{2}{*}{ Treatments* } & \multicolumn{5}{|c|}{ Volatile Solids } \\
\hline & Influent & Effluent & Influent & Effluent & Reduction \\
\hline & 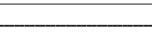 & 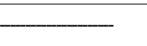 & 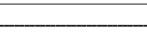 & 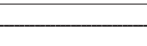 & $\%$ \\
\hline NC & $0.44 \mathrm{~A}$ & 0.13 B & $0.0088 \mathrm{~A}$ & 0.0026 B & $70 \mathrm{~A}$ \\
\hline DFM & $0.33 \mathrm{~B}$ & $0.15 \mathrm{AB}$ & 0.0066 B & $0.0029 A B$ & $54 \mathrm{~B}$ \\
\hline ENZ & $0.34 \mathrm{~B}$ & $0.16 \mathrm{~A}$ & 0.0068 B & $0.0031 \mathrm{~A}$ & $55 B$ \\
\hline $\mathrm{DFM}+\mathrm{E}$ & $0.38 \mathrm{AB}$ & $0.14 \mathrm{AB}$ & $0.0076 \mathrm{AB}$ & $0.0028 \mathrm{AB}$ & $62 A B$ \\
\hline F values & 6.14 & 4.12 & 6.13 & 4.14 & 7.24 \\
\hline$P$ values & $0.0090^{* *}$ & $0.0032^{* *}$ & $0.0090^{* *}$ & $0.0314^{* *}$ & $0.0050^{* *}$ \\
\hline $\mathrm{CV}^{1}(\%)$ & 10 & 7 & 10 & 7 & 9 \\
\hline
\end{tabular}

${ }^{1}$ Coefficient of variation; ${ }^{*} \mathrm{NC}=$ negative control; DFM $=\mathrm{NC}+500 \mathrm{ppm}$ of direct fed microbials (DFM) with Bacillus subtilis and Bacillus licheniformis; ENZ = diet formulated with an enzyme blend (20 ppm phytase, 200 ppm protease and 200 ppm xylanase); DFM+E = ENZ + DFM; ${ }^{* *} p \leq 0.05 ;{ }^{N S} n o n-s i g n i f i c a n t ; ~ A-B=$ means followed by different letters within a column are significantly different $(p \leq 0.05)$ according to Tukey test.

Table 2 - Amounts of neutral detergent fiber (NDF), acid detergent fiber (ADF) and lignin in influents, effluents and \% degraded fiber from litter of broilers fed diets with direct fed microbials (DFM) and enzymes, treated in continuous bio-digesters.

\begin{tabular}{|c|c|c|c|c|c|c|c|c|c|}
\hline \multirow[t]{2}{*}{ Treatments* } & \multicolumn{3}{|c|}{$\begin{array}{c}\text { Influent } \\
\text { g } 100 \mathrm{~g}^{-1} \mathrm{DM} \%\end{array}$} & \multicolumn{3}{|c|}{$\begin{array}{c}\text { Effluent } \\
\text { g } 100 \mathrm{~g}^{-1} \mathrm{DM} \%\end{array}$} & \multicolumn{3}{|c|}{ \% Degraded } \\
\hline & NDF & ADF & Lignin & NDF & ADF & Lignin & NDF & ADF & Lignin \\
\hline$\overline{N C}$ & $11.84 \mathrm{C}$ & $4.92 \mathrm{C}$ & $1.89 \mathrm{C}$ & 2.25 & 1.12 & 0.75 & $91 \mathrm{~B}$ & 89 & 80 \\
\hline PRO & $18.59 \mathrm{~B}$ & $7.65 \mathrm{~B}$ & $1.68 \mathrm{D}$ & 3.41 & 1.76 & 0.76 & $90 \mathrm{~B}$ & 88 & 76 \\
\hline ENZ & $24.30 \mathrm{~A}$ & $8.23 \mathrm{~A}$ & $2.63 \mathrm{~A}$ & 2.22 & 1.10 & 0.55 & $95 \mathrm{~A}$ & 93 & 89 \\
\hline $\mathrm{P}+\mathrm{E}$ & $24.98 \mathrm{~A}$ & $8.35 \mathrm{~A}$ & $2.03 \mathrm{~B}$ & 2.11 & 0.97 & 0.40 & $96 \mathrm{~A}$ & 94 & 88 \\
\hline F values & 793.93 & 74.94 & 178.18 & 1.14 & 1.38 & 0.61 & 3.65 & 2.17 & 0.374 \\
\hline$P$ values & $<0.0001^{* *}$ & $<0.0001^{* *}$ & $<0.0001^{* *}$ & $0.372^{\mathrm{NS}}$ & $0.2969^{\text {NS }}$ & $0.623^{\text {NS }}$ & $0.044^{* *}$ & $0.144^{\text {NS }}$ & $1.13^{\mathrm{NS}}$ \\
\hline $\mathrm{CV}^{1}(\%)$ & 1 & 2 & 3 & 45 & 48 & 60 & 3 & 4 & 14 \\
\hline
\end{tabular}

${ }^{1}$ Coefficient of variation; ${ }^{*} \mathrm{NC}=$ negative control; DFM $=\mathrm{NC}+500 \mathrm{ppm}$ of direct fed microbials (DFM) with Bacillus subtilis and Bacillus licheniformis; ENZ = diet formulated with an enzyme blend (20 ppm phytase, 200 ppm protease and 200 ppm xylanase); DFM+E = ENZ + DFM; * $p \leq 0.05 ;{ }^{*}$ non-significant; A-B = means followed by different letters within a column are significantly different $(p \leq 0.05)$ according to the Tukey test. 
the fiber fraction, which explains the higher degradation achieved in treatments that included enzymes (Table 2).

The different diets interfered $(p<0.05)$ in the average concentration of nutrients $(\mathrm{N}, \mathrm{P}$ and $\mathrm{K})$ present in the effluents of poultry litter treated in continuous bio-digesters. Effluents from the litter of broilers fed enzymes and DFM combination had higher average con-

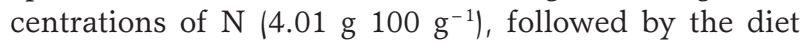

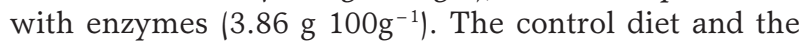
diet with DFM had the lowest concentrations (3.72 and

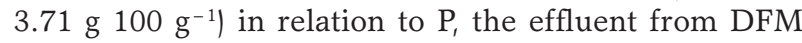

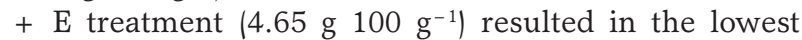
concentrations, and these were no different from those

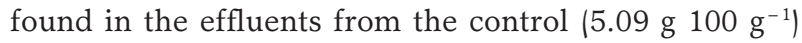

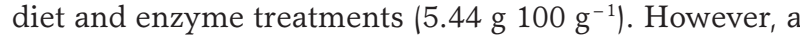
higher concentration of $\mathrm{P}$ was in the treatment containing DFM (5.77 g $100 \mathrm{~g}^{-1}$ ). The lowest $\mathrm{K}$ concentrations were reported in the enzymes and enzymes + DFM

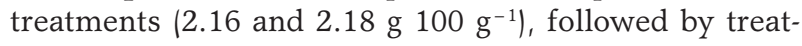
ment control and DFM (2.51 and $3.23100 \mathrm{~g}^{-1}$ ) (Table 3).

The increase in $\mathrm{N}$ and $\mathrm{K}$ amounts in the biofertilizers (effluents) when compared to the amounts in the material used to load the bio-digesters was expected. Residues in general undergoing anaerobic bio-digestion lose carbon as $\mathrm{CH}_{4}$ and $\mathrm{CO}_{2}$, resulting in concentration of the other nutrients, in disagreement with the phosphorus data in the present study. This result can be associated with the physical-chemical removal by means of these compounds' precipitation.

The number of total and thermotolerant groups of coliforms in influents and effluents of litters from animals receiving feed additives were lower when compared to the control treatment in all analyzed time periods analyzed (30,60 and 85 days) (Table 4). In all the treatments, efficiency of treatment in continuous bio-digesters was higher than $90 \%$ for fecal and thermotolerant coliforms only in the final sample collection period (85 days) (Table 4).

The potential contamination of soil and water by effluent pathogens should be better studied as the level of fecal coliforms present in bio-digester effluents de- pend on a higher hydraulic retention time (HRT) and temperature for the treatment to become more efficient. This treatment is more restricted in continuous bio-digesters than in batch bio-digesters. According to Côté et al. (2006), a reduction in efficiency of pathogenic microorganisms is associated with the fermentation temperature and TRH used; therefore, the higher the values, the more effective the production of pathogens.

According to CONAMA Resolution 357/05, that classifies waters to be used in irrigation as class 2 , the maximum limit is 1000 thermotolerant (fecal) coliforms in a $100 \mathrm{~mL}$ sample (CONAMA, 2005). Therefore, the effluent produced by the continuous bio-digester during the experimental period would be above the standard and could not be used in fertirrigation. Total elimination of both fecal and thermotolerant coliforms stresses the importance and efficiency of the anaerobic bio-digestion process in reducing the organisms responsible for fecal pollution.

Diet influenced $(p<0.05)$ the substrates in biogas production and potential production (Table 5). Biodigesters with litter from birds that were only fed diets with enzymes (ENZ) had the highest biogas production both daily and accumulated $\left(\mathrm{m}^{3}\right)$, and methane $\left(\mathrm{m}^{3}\right)$ (Table 5), with no difference in relation to the control treatment. In relation to the other treatments, the same happened with biogas production potential per $\mathrm{kg}$ of added and reduced TS and VS (Table 5).

Another explanation for the reduction in biogas production is that these bacteria, when added to the feed, increase degradation of the substrate, using nutrients present in the litter during the period these were stored. Thus, the use of Bacillus bacteria in the broilers' diet and their influence on biogas production will depend on the time the litter was stored and the production of antimicrobials (Tables 5 and 6).

However, Praes et al. (2013) did not find in their study a negative influence of the broilers' diets with DFM on the production of biogas and methane, when treating broiler droppings in batch bio-digesters. In relation to the control treatment, there was a $27 \%$ increase

Table 3 - Mineral and macro nutrient composition, nitrogen (N), phosphorus (P) and potassium (K), of influents and effluents from litter of broilers fed diets with direct fed microbials (DFM) and enzymes, treated in continuous bio-digesters.

\begin{tabular}{|c|c|c|c|c|c|c|}
\hline \multirow{2}{*}{ Treatments* } & \multicolumn{3}{|c|}{$\begin{array}{c}\text { Influent } \\
\text { g } 100 \mathrm{~g}^{-1} \mathrm{DM} \%\end{array}$} & \multicolumn{3}{|c|}{$\begin{array}{c}\text { Effluent } \\
\text { g } 100 \mathrm{~g}^{-1} \mathrm{DM} \%\end{array}$} \\
\hline & $\mathrm{N}$ & $P$ & K & $\mathrm{N}$ & $P$ & K \\
\hline$\overline{\mathrm{NC}}$ & 2.35 & 6.44 & 1.15 & $3.72 \mathrm{C}$ & $5.09 A B$ & $2.51 \mathrm{~B}$ \\
\hline DFM & 2.36 & 6.25 & 1.23 & $3.71 \mathrm{C}$ & $5.77 \mathrm{~A}$ & $3.23 \mathrm{~A}$ \\
\hline ENZ & 2.24 & 5.60 & 1.20 & $3.86 \mathrm{~B}$ & $5.44 \mathrm{AB}$ & $2.16 \mathrm{C}$ \\
\hline $\mathrm{DFM}+\mathrm{E}$ & 2.20 & 6.32 & 1.21 & $4.01 \mathrm{~A}$ & $4.65 \mathrm{~B}$ & $2.18 \mathrm{C}$ \\
\hline F values & 4.82 & 2.45 & 1.76 & 34.95 & 5.62 & 73.98 \\
\hline$P$ values & $0.21^{\mathrm{NS}}$ & $0.11^{\mathrm{NS}}$ & $0.21^{\mathrm{NS}}$ & $<0.0001^{* *}$ & $0.012^{* *}$ & $<0.0001^{* *}$ \\
\hline CV1 $(\%)$ & 4 & 8 & 5 & 1 & 8 & 1 \\
\hline
\end{tabular}

${ }^{1}$ Coefficient of variation; ${ }^{\star} \mathrm{NC}=$ negative control; DFM $=\mathrm{NC}+500 \mathrm{ppm}$ of direct fed microbials (DFM) with Bacillus subtilis and Bacillus licheniformis; ENZ = diet formulated with an enzyme blend (20 ppm phytase, 200 ppm protease and 200 ppm xylanase); DFM+E $=E N Z+D F M$; ${ }^{*} p \leq 0.05$; ${ }^{*}$ non-significant; A-B = means followed by different letters within a column are significantly different $(p \leq 0.05)$ according to the Tukey test. 
Table 4 - Most probable number of total and thermotolerant coliform organisms (MPN $100 \mathrm{~mL}^{-1}$ ) and efficiency (\%) of treating litter of broilers fed diets with direct fed microbials (DFM) and enzymes, in continuous bio-digesters in 30, 60, and 85 days.

\begin{tabular}{|c|c|c|c|c|c|c|}
\hline \multirow{3}{*}{ Treatments* } & \multicolumn{6}{|c|}{30 Days } \\
\hline & \multicolumn{2}{|c|}{$\begin{array}{l}\text { Total coliforms } \\
\text { (MPN } 100 \mathrm{~mL}^{-1} \text { ) }\end{array}$} & \multirow{2}{*}{ Efficiency (\%) } & \multicolumn{2}{|c|}{$\begin{array}{l}\text { Thermotolerant coliforms } \\
\text { (MPN } 100 \mathrm{~mL}^{-1} \text { ) }\end{array}$} & \multirow[t]{2}{*}{ Efficiency (\%) } \\
\hline & Influent & Effluent & & Influent & Effluent & \\
\hline NC & $9.30 \times 10^{7} \mathrm{~A}$ & $0.780 \times 10^{7} \mathrm{~A}$ & 92 & $9.30 \times 10^{7} \mathrm{~A}$ & $0.780 \times 10^{7} \mathrm{~A}$ & 92 \\
\hline DFM & $0.17 \times 10^{7} \mathrm{~B}$ & $0.068 \times 10^{7} \mathrm{~B}$ & 6 & $0.17 \times 10^{7} \mathrm{~B}$ & $0.068 \times 10^{7} \mathrm{~B}$ & 60 \\
\hline ENZ & $0.14 \times 10^{7} \mathrm{~B}$ & $0.110 \times 10^{7} \mathrm{~B}$ & 21 & $0.09 \times 10^{7} \mathrm{~B}$ & $0.110 \times 10^{7} \mathrm{~B}$ & 88 \\
\hline \multirow[t]{2}{*}{$\mathrm{DFM}+\mathrm{E}$} & $0.78 \times 10^{7} \mathrm{~B}$ & $0.680 \times 10^{7} \mathrm{~B}$ & 13 & $0.45 \times 10^{7} \mathrm{~B}$ & $0.200 \times 10^{7} \mathrm{~B}$ & 56 \\
\hline & \multicolumn{6}{|c|}{60 Days } \\
\hline \multirow[t]{2}{*}{ Treatments* } & \multicolumn{2}{|c|}{$\begin{array}{l}\text { Total coliforms } \\
\text { (MPN } 100 \mathrm{~mL}^{-1} \text { ) }\end{array}$} & Efficiency (\%) & \multicolumn{2}{|c|}{$\begin{array}{l}\text { Thermotolerant coliforms } \\
\text { (MPN } 100 \mathrm{~mL}^{-1} \text { ) }\end{array}$} & Efficiency (\%) \\
\hline & Influent & Effluent & & Influent & Effluent & \\
\hline$\overline{N C}$ & $9.30 \times 10^{7} \mathrm{~A}$ & $0.065 \times 10^{7} \mathrm{~A}$ & 99 & $9.30 \times 10^{7} \mathrm{~A}$ & $0.065 \times 10^{7} \mathrm{~A}$ & 99 \\
\hline DFM & $0.17 \times 10^{7} \mathrm{~B}$ & $0.004 \times 10^{7} \mathrm{~B}$ & 97 & $0.17 \times 10^{7} \mathrm{~B}$ & $0.004 \times 10^{7} \mathrm{~B}$ & 97 \\
\hline ENZ & $0.14 \times 10^{7} \mathrm{~B}$ & $0.012 \times 10^{7} \mathrm{~B}$ & 91 & $0.09 \times 10^{7} \mathrm{~B}$ & $0.008 \times 10^{7} \mathrm{~B}$ & 91 \\
\hline \multirow[t]{2}{*}{$\mathrm{DFM}+\mathrm{E}$} & $0.78 \times 10^{7} \mathrm{~B}$ & $0.020 \times 10^{7} \mathrm{~B}$ & 97 & $0.45 \times 10^{7} \mathrm{~B}$ & $0.018 \times 10^{7} \mathrm{~B}$ & 96 \\
\hline & \multicolumn{6}{|c|}{85 Days } \\
\hline \multirow[t]{2}{*}{ Treatments* } & \multicolumn{2}{|c|}{$\begin{array}{l}\text { Total coliforms } \\
\text { (MPN } 100 \mathrm{~mL}^{-1} \text { ) }\end{array}$} & Efficiency (\%) & \multicolumn{2}{|c|}{$\begin{array}{l}\text { Thermotolerant coliforms } \\
\text { (MPN } 100 \mathrm{~mL}^{-1} \text { ) }\end{array}$} & Efficiency (\%) \\
\hline & Influent & Effluent & & Influent & Effluent & \\
\hline$\overline{N C}$ & $9.30 \times 10^{7} \mathrm{~A}$ & $0.0005 \times 10^{7} \mathrm{~A}$ & 99 & $9.30 \times 10^{7} \mathrm{~A}$ & $0.0005 \times 10^{7} \mathrm{~A}$ & 99 \\
\hline DFM & $0.17 \times 10^{7} \mathrm{~B}$ & $0.0002 \times 10^{7} B$ & 99 & $0.17 \times 10^{7} \mathrm{~B}$ & $0.0002 \times 10^{7} B$ & 99 \\
\hline ENZ & $0.14 \times 10^{7} \mathrm{~B}$ & $0.0001 \times 10^{7} \mathrm{~B}$ & 99 & $0.09 \times 10^{7} \mathrm{~B}$ & $0.0001 \times 10^{7} B$ & 99 \\
\hline $\mathrm{DFM}+\mathrm{E}$ & $0.78 \times 10^{7} \mathrm{~B}$ & $0.0002 \times 10^{7} \mathrm{~B}$ & 99 & $0.45 \times 10^{7} \mathrm{~B}$ & $0.0002 \times 10^{7} \mathrm{~B}$ & 99 \\
\hline
\end{tabular}

${ }^{*} \mathrm{NC}$ : negative control; DFM: NC +500 ppm of direct fed microbials (DFM) with Bacillus subtilis and Bacillus licheniformis; ENZ: diet formulated with an enzyme blend (20 ppm phytase, $200 \mathrm{ppm}$ protease and $200 \mathrm{ppm}$ xylanase); DFM+E: ENZ + DFM. ${ }^{\star \star} p \leq 0.05$. A-B: means followed by different letters within a column are significantly different $(p \leq 0.05)$ according to Tukey test.

Table 5 - Daily and accumulated volume ( $\mathrm{mL}$ ), potential of gas production by Total Solids (TS) and Volatile Solids (VS) added and reduced $\left(\mathrm{mL} \mathrm{kg}^{-1}\right)$, from litter of broilers fed diets with direct fed microbials (DFM) and enzymes, treated in continuous bio-digesters.

\begin{tabular}{|c|c|c|c|c|c|c|}
\hline \multirow{3}{*}{ Treatments* } & \multirow{2}{*}{\multicolumn{2}{|c|}{ Volume }} & \multicolumn{4}{|c|}{ Potential } \\
\hline & & & \multicolumn{2}{|c|}{ TS } & \multicolumn{2}{|c|}{ VS } \\
\hline & Daily & Accumulated & Added & Reduction & Added & Reduction \\
\hline & \multicolumn{2}{|c|}{$\mathrm{mL}$} & \multicolumn{4}{|c|}{$\mathrm{mL} \mathrm{kg}^{-1}$} \\
\hline NC & $6.3010^{3} \mathrm{~A}$ & $0.5310^{6} \mathrm{~A}$ & $0.4410^{6} \mathrm{~A}$ & $0.8810^{6} \mathrm{~B}$ & $0.7210^{6} \mathrm{~B}$ & $1.0210^{6} \mathrm{C}$ \\
\hline DFM & $5.5010^{3} \mathrm{~B}$ & $0.4710^{6} \mathrm{~B}$ & $0.3810^{6} \mathrm{~B}$ & $0.8010^{6} \mathrm{~B}$ & $0.7610^{6} \mathrm{~B}$ & $1.4010^{6} \mathrm{~B}$ \\
\hline ENZ & $6.4010^{3} \mathrm{~A}$ & $0.5510^{6} \mathrm{~A}$ & $0.4610^{6} \mathrm{~A}$ & $1.0010^{6} \mathrm{~A}$ & $0.9410^{6} \mathrm{~A}$ & $1.7410^{6} \mathrm{~A}$ \\
\hline $\mathrm{DFM}+\mathrm{E}$ & $5.8010^{6} \mathrm{~B}$ & $0.4810^{6} \mathrm{~B}$ & $0.4110^{6} \mathrm{~B}$ & $0.8810^{6} \mathrm{~B}$ & $0.7510^{6} \mathrm{~B}$ & $1.2510^{6} \mathrm{~B}$ \\
\hline F values & 6.96 & 6.99 & 10.17 & 11.92 & 21.25 & 65.48 \\
\hline$P$ values & $0.006^{* *}$ & $0.006^{* *}$ & $0.001^{* *}$ & $0.0007^{* *}$ & $<0.0001^{* *}$ & $<0.0001^{* *}$ \\
\hline $\mathrm{CV}^{1}(\%)$ & 5 & 5 & 5 & 5 & 5 & 6 \\
\hline
\end{tabular}

${ }^{1}$ Coefficient of variation; ${ }^{*} \mathrm{NC}=$ negative control; $\mathrm{DFM}=\mathrm{NC}+500 \mathrm{ppm}$ of direct fed microbials (DFM) with Bacillus subtilis and Bacillus licheniformis; ENZ $=$ diet formulated with an enzyme blend (20 ppm phytase, 200 ppm protease and $200 \mathrm{ppm}$ xylanase); DFM+E =ENZ + DFM; ${ }^{* *} p \leq 0.05 ;{ }^{N s}$ non-significant; $A-B=$ means followed by different letters within a column are significantly different $(p \leq 0.05)$ according to Tukey test.

in biogas production per kg of added TS. Therefore, data were contradictory to those in the present study, where treatments containing DFM obtained lower production of methane and biogas. Highest biogas production was obtained in the litter of birds fed with diet containing enzyme complex (Table 5).

According to Kocher et al. (2003), the feed enzymes cause the rupture of fiber cell walls, degrade proteins, and decrease the effects of antinutritional factors, so that nutrients become more available both for the animal and the anaerobic bacteria present in biodigesters. The higher nutrients' availability increases biogas production.

\section{Conclusions}

When added to the diet of broilers, enzymes increase the amount of organic matter and nutrients in poultry litter. DFM and DFM + E inhibited the production of biogas and methane. 
Table 6 - Daily volume $(\mathrm{mL})$ and composition of biogas, methane $\left(\mathrm{CH}_{4}\right)$, carbon dioxide $\left(\mathrm{CO}_{2}\right)$ and other gases (mL and \%) produced from litter of broilers fed diets with direct fed microbials (DFM) and enzymes, treated in continuous bio-digesters.

\begin{tabular}{|c|c|c|c|c|c|c|}
\hline \multirow{2}{*}{ Treatments* } & \multicolumn{3}{|c|}{$\begin{array}{l}\text { Volume } \\
\text { (mL) }\end{array}$} & \multicolumn{3}{|c|}{$\begin{array}{c}\text { Proportion } \\
\text { (\%) }\end{array}$} \\
\hline & Biogas & $\mathrm{CH}_{4}$ & $\mathrm{CO}_{2}$ & $\mathrm{CH}_{4}$ & $\mathrm{CO}_{2}$ & Other gases \\
\hline$\overline{\mathrm{NC}}$ & $6.3010^{3} \mathrm{~A}$ & $4.4010^{3} \mathrm{~A}$ & $1.7010^{3} \mathrm{AB}$ & 71 & 28 & 1.18 \\
\hline DFM & $5.5010^{3} \mathrm{~B}$ & $4.0010^{3} \mathrm{~B}$ & $1.0510^{3} \mathrm{~B}$ & 72 & 27 & 1.28 \\
\hline ENZ & $6.4010^{3} \mathrm{~A}$ & $4.5010^{3} \mathrm{~A}$ & $1.8010^{3} \mathrm{~A}$ & 71 & 28 & 1.11 \\
\hline $\mathrm{DFM}+\mathrm{E}$ & $5.8010^{6} \mathrm{~B}$ & $4.1010^{3} \mathrm{~B}$ & $1.6010^{3} \mathrm{AB}$ & 71 & 28 & 1.08 \\
\hline F values & 6.96 & 7.77 & 5.25 & 0.83 & 1.89 & 0.17 \\
\hline$P$ values & $0.006^{* *}$ & $0.004^{* *}$ & $0.015^{* *}$ & $0.50^{\mathrm{NS}}$ & $0.19^{\mathrm{NS}}$ & $0.91^{\mathrm{NS}}$ \\
\hline $\mathrm{CV}^{1}(\%)$ & 5 & 5 & 7 & 1 & 3 & 4 \\
\hline
\end{tabular}

${ }^{1}$ Coefficient of variation; ${ }^{*} \mathrm{NC}=$ negative control; DFM $=\mathrm{NC}+500 \mathrm{ppm}$ of direct fed microbials (DFM) with Bacillus subtilis and Bacillus licheniformis; ENZ $=$ diet formulated with an enzyme blend (20 ppm phytase, $200 \mathrm{ppm}$ de protease and $200 \mathrm{ppm}$ de xylanase); DFM+E = ENZ + DFM; ${ }^{* *} p \leq 0.05$; ${ }^{\mathrm{NS}}$ non-significant; $A-B=$ means followed by different letters within a column are significantly different $(p \leq 0.05)$ according to the Tukey test.

Treating broiler litter in continuous bio-digesters reduces $\mathrm{pH}$, total solids, volatile solids, fibers that are difficult to degrade, and fecal and thermotolerant coliforms present in their effluents, thus reducing the pollutant potential of residues from poultry production. More non-complexed nutrients become available for use in soil, particularly nitrogen and potassium.

However, despite the bacteria being removed after the digestion process, a significant number of pathogens were found, which means that auxiliary treatment processes are needed in order to minimize environmental pollution.

\section{Acknowledgements}

DSM for providing DFM and exogenous enzymes. FAPESP for the scholarship and financial support to the project (2010/05263-1; 2010/11329-5).

\section{References}

American Public Health Association [APHA]. 2005. Standard Methods for Examination of Water and Wastewater. 21ed. APHA/AWWA/WPCF, Washington, DC, USA.Association of Official Analytical Chemists International [AOAC]. 2005. Official Methods of Analysis. 18ed. AOAC, Gaithersburg, MD, USA.

Bolan, N.S.; Szogi, A.A.; Chuavasathi, T.; Seshadri, B.; Rothrock Jr., M.J.; Panneerselvam, P. 2010. Uses and management of poultry litter. World's Poultry Science Journal 66: 673-698.

Conselho Nacional de Meio Ambiente [CONAMA]. 2005. Resolution $\mathrm{n}^{\circ}$ 357. = Resolução $\mathrm{n}^{\circ}$ 357. Diário Oficial da União, Brasília, DF, Brazil (in Portuguese).

Côté, C.; Masse, D.I.; Quessy, S. 2006. Reduction of indicator and pathogenic microorganisms by psychrophilic anaerobic digestion in swine slurries. Bioresource Technology 97: 686691.
Demirer, G.N.; Chen, S. Two-phase anaerobic digestion of unscreened dairy manure. 2005. Process Biochemistry 40: 3542-3549.

Food and Agriculture Organization of the United Nations [FAO]. 2011. Preservation and Processing Technologies to Improve Availability and Safety of Meat and Meat Products in Developing Countries. World Animal Review. FAO, Rome, Italy.

Food and Agriculture Organization [FAO]. 1996. A System Approach to Biogas Technology: A Trainning Manual for Extension. FAO, Rome, Italy

Huyghebaert, G.; Ducatelle, R.; Van Immerseel, F. 2011. An update on alternatives to antimicrobial growth promoters for broilers. The Veterinary Journal 187: 182-188.

Kocher, A.; Choct, M.; Ross, G.; Broz, J.; Chung, T.K. 2003. Effects of enzyme combinations on apparent metabolizable energy of corn-soybean meal-based diets in broilers. Journal of Applied Poultry Research 12: 275-283.

Malavolta, E. 1989. Micronutrients: an overview. = Micronutrientes: uma visão geral. p. 1-33. In: Ferreira, M.E.; Cruz, M.C. Micronutrients in agriculture $=$ Micronutrientes na agricultura. POTAFOS, Piracicaba, SP, Brazil (in Portuguese).

Nahm, K.H.; Nahm, B.A. 2004. Poultry Production and Waste Management. Yu Han Publishing, Beijing, China.

National Research Council [NRC]. 1994. Nutrients Requeriments of Poultry. 9ed. National Research Council, Washington, DC, USA.

Orrico Junior, M.A.P.; Orrico, A.C.A.; Lucas Junior, J. 2010. Effects of roughage: concentrate in relation to time of hydraulic retention under anaerobic biodigestion of cattle manure Brazil. Engenharia Agrícola 30: 386-394 (in Portuguese, with abstract in English).

Praes, M.F.M.; Lucas Junior, J.; Hermes; R.; Sorbara, J.O.B.; Ferreira, L.M.S.; Cardoso, P.B.C.S. 2013. Effect of a broiler diet containing probiotic and exogenous enzymes on the manure used for biogas production. Sustainable Agriculture Innovation 20: $322-328$ 